\title{
UPAYA MENINGKATKAN PRESTASI BELAJAR BAHASA INDONESIA DENGAN METODE PERMAINAN EDUKATIF DALAM MEMBUAT PANTUN SISWA KELAS IV SD MUHAMMADIYAH
}

\author{
IMPROVING THE STUDENTS' ACHIVEMENT OF INDONESIAN \\ LANGUAGE LEARNING BY USING EDUCATION GAMES IN WRITING \\ POETRY TO THE FOURTH GRADES STUDENTS AT SD \\ MUHAMMADIYAH
}

Juriyah

SD Muhammadiyah Bausasran Yogyakarta

\begin{abstract}
The objectives of this research is to know the application of education game to improve the students' achievement on Indonesia language learning in writing poetry to the fourth grade students at SD Muhammadiyah Bausasran. This research belongs to Classroom Action Research (CAR). The subject of the research was the fourth grade students of SD Muhammadiyah Bausasran in the academic year 2013/2014 which consisted of 24 students. The research was conducted in two cycles, and there were one meeting in every cycle. The data were collected by doing observation, conducting interview, distributing questionnaire, and giving test (pre-test and post-test). The writer used descriptive qualitative technique to analyze the data from the result. Based on the data result, it can be concluded that the application of education game is able to improve the students' achievement on Indonesia language learning in writing poetry to the fourth grade students at SD Muhammadiyah Bausasran. The result can be seen from the mean score of pre-cycle was 66.75. In the cycle I, the mean score of students' achievement was 70.33. Meanwhile the mean score of student's achievement in the cycle II was 78.91. The average of students achievement was improve from the cycle I was $3,58 \%$, while the improvement from the cycle I to the cycle II was $8,58 \%$.

Key words: education games, poetry, students' achievement, Indonesia language learning.

Tujuan penelitian ini adalah untuk mengetahui penerapan permainan edukatif untuk meningkatkan prestasi siswa pada pembelajaran bahasa Indonesia dalam menulis puisi untuk siswa kelas IV SD Muhammadiyah Bausasran. Penelitian ini termasuk Penelitian Tindakan Kelas (PTK). Subyek penelitian ini adalah siswa kelas IV SD Muhammadiyah Bausasran pada tahun akademik 2013/2014 yang terdiri dari 24 siswa. Penelitian ini dilakukan dalam dua siklus, dan ada satu pertemuan di setiap siklus. Data dikumpulkan dengan melakukan observasi, wawancara, penyebaran kuesioner, dan memberikan tes (pre-test dan post-test). Penulis menggunakan teknik deskriptif kualitatif untuk menganalisis data dari hasil penelitian. Berdasarkan analisis data, dapat disimpulkan bahwa penerapan permainan edukatif mampu meningkatkan prestasi siswa pada pembelajaran bahasa Indonesia dalam menulis puisi untuk siswa kelas IV SD Muhammadiyah
\end{abstract}


Bausasran. Hasil dapat dilihat dari nilai rata-rata pra-siklus adalah 66,75. Pada siklus I, nilai rata-rata prestasi siswa adalah 70,33. Sementara nilai rata-rata prestasi siswa pada siklus II adalah 78,91. Rata-rata prestasi siswa adalah meningkat dari siklus I adalah 3,58\%, sedangkan peningkatan dari siklus I ke siklus II adalah $8,58 \%$.

Kata kunci: game pendidikan, puisi, prestasi siswa, pembelajaran bahasa Indonesia.

\section{Pendahuluan}

Guru berperan sebagai pengelola proses pembelajaran, bertindak sebagai fasilitator yang berusaha menciptakan kondisi pembelajaran yang efektif, sehingga memungkinkan proses pembelajaran berjalan dengan lancar, mengembangkan bahan pembelajaran dengan baik, serta meningkatkan kemampuan siswa untuk memperhatikan pembelajaran dan menguasai tujuantujuan pendidikan yang hendak dicapai.

Permainan Edukatif bukan hal asing lagi di kalangan pendidik dan ahli psikologi. Banyak juga berbagai yang mengupas tuntas mengenai " Permainan Edukatif" tersebut, mulai dari media cetak, majalah, buku, sampai media elektronika berbagai stasiun televise, radio, dan berbagai situs di internet. Kenyataannya terlihat tidak begitu berpengaruh atau tidak dilaksanakan pada pembelajaran di sekolah terutama di Sekolah Dasar .Memang terlihat sepintas dengan kata "permainan" terkesan lebih santai dan ringan, hanya membuang waktu belajar anak- anak, terutama bagi pada orang tua dan guru yang cenderung mengutamakan akademis sebagai tolok ukur keberhasilan anak dalam belajar.

Prinsip bermain sambil belajar sepintas memang agak mengesampingkan aktifitas belajar. Jika diamati secara mendalam maksud dari prinsip tersebut adalah aktivitas bermain secara tidak langsung membawa anak untuk belajar tanpa adanya beban dan batas bahwa mereka lebih menikmati belajar mereka karena tidak ada paksaan. Di sinilah fungsi bermain sebenarnya, yaitu bermain yang dapat mendidik anak.

Pelajaran bahasa Indonesia adalah pelajaran pokok yang memiliki empat kompetensi / kemampuan yang harus dicapai anak, yaitu kemampuan membaca, mendengarkan, berbicara, dan menulis. Pelajaran bahasa Indonesia dapat dikatakan sebagai pelajaran pondasi, karena dalam pelajaran bahasa Indonesia 
inilah anak diajari membaca dan menulis, tanpa dasar membaca dan menulis maka mata pelajaran yang lain sulit dipahami.

Dalam pembelajaran anak- anak merasa terpaksa, karena harus duduk berjam- jam dan diam mendengarkan guru ceramah, bahkan ketika diberi kesempatan untuk bertanya, mereka tidak tahu dan bahkan tidak berani apa yang harus ditanyakan. Demikian pula ketika ditanya oleh guru, mereka tidak tahu bagaimana menjawabnya. Pembelajaran juga hanya di ruang kelas. Guru kurang memahami bagaimana caranya agar siswa mengalami proses belajar yang optimal. Selain itu kurikulum yang sarat dengan berbagai materi pelajaran tidak akan memberikan kesempatan kepada guru untuk mengaktifkan siswa belajar. Guru merasa terbebani untuk menyelesaikan materi pelajaran yang sudah ditetapkan di dalam kurikulum untuk diselesaikan pada waktu yang sudah ditentukan pula. Di sisi lain ada tuntutan dari masyarakat output dari sekolah yang bersangkutan memiliki nilai atau hasil ujian yang memuaskan orang tua.

Pembelajaran pantun akan lebih ideal dengan teknik permainan yaitu berbalas pantun dan bermain kartu kata.Membuat pantun dengan permainan kartu kata serta mengungkapkan dengan berbalas pantun, merupakan salah satu ketrampilan berbahasa, yang mampu mengungkapkan ide, gagasan (pendapat) siswa berupa lisan dan tulisan, serta keaktifan siswa dalam berkreasi. Sehingga anak akan lebih bersaing dengan teman yang lain. Dalam pembelajaran ini siswa dapat berdiskusi sesuai dengan kelompoknya dan belajar bersama pasangannya, sehingga siswa tidak akan tergantung pada guru. Guru hanya memberi penjelasan sebelum pelajaran dimulai, dan selanjutnya hanya sebagai fasilitator saja, sedangkan siswa sebagai pelaku utama dalam pembelajaran.

Pembelajaran ini lebih efektif dan kreatif dalam membangkitkan semangat belajar siswa, karena persaingan dengan teman terlihat lebih jelas.Ini semua berarti bahwa dalam sebuah pembelajaran siswa seharusnya lebih aktif daripada guru, bukan sebaliknya guru lebih aktif daripada siswanya. Metode ini diharapkan mampu meningkatkan keaktifan siswa sehingga prestasi siswa juga akan meningkat terutama dalam mata pelajaran bahasa Indonesia. 


\section{Metode Penelitian}

Penelitian ini menggunakan penelitian tindakan kelas yang bertujuan untuk mengetahui bagaimana pelaksanaan penerapan permainan edukatif dalam siklus berulang. Secara umum ada empat tahap dalam penelitian tindakan kelas yaitu perencanaan, tindakan, pengamatan, dan refleksi. Tahap- tahap tersebut digambarkan sebagai berikut :

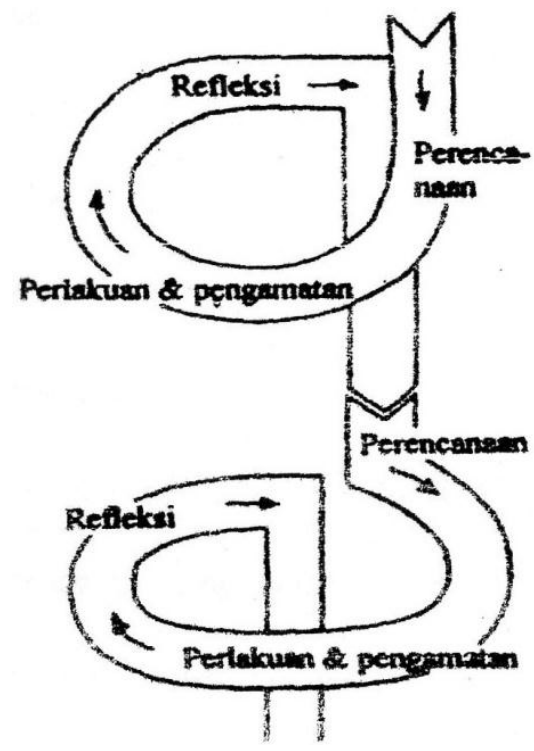

Gambar 1. Alur Penelitian Tindakan Kelas Model Suharsimi dalam Triani (2008:

Penelitihan ini dilaksanakan di SD.Muhammadiyah Bausasran, Jalan Ronodigdayan no.60 Yogyakarta. Jumlah siswa kelas IV berjumlah siswa 24 siswa, terdiri siswa perempuan ada 10, sedangkan siswa laki- laki ada 14. Penelitian tindakan kelas ini dilakukan dalam empat tahap, yaitu:

\section{a. Perencanaan}

Tahap ini adalah menentukan materi pembuatan pantun dengan metode permainan educative yaitu dengan permainan suku kata dan berbalas pantun. Selanjutnya menyusun scenario pembelajaran dengan menyusun RPP, menyusun Lembar Kerja Siswa (LKS), menyusun indicator pencapaian kompetensi, serta membuat format observasi guru dan siswa.

\section{b. Pelaksanaan tindakan}


Proses pelaksanaan pembelajaran bahasa Indonesia dengan penerapan permainan educative dengan menggunakan kartu kata serta berbalas pantun. Proses pembelajaran di sini sejak awal sampai akhir pelaksanaan pembelajaran dengan penerapan permainan edukatif. Tidak hanya saat penerapan permainan educative saja, tetapi secara menyeluruh dalam satu rangkaian pembelajaran yaitu persiapan, proses, dan evaluasi hasil pembelajaran. Fokus utama dalam penelitian ini adalah penggunaan metode permainan edukatif dalam meningkatkan prestasi belajar bahasa Indonesia dalam membuat pantun siswa kelas IV SD. Muhammadiyah Bausasran Yogyakarta.

\section{c. Pengamatan (Observasi)}

Observasi di sini berfungsi untuk mendokumentasikan pengaruh tindakan terkait bersama prosesnya. Observasi dilakukan saat mengganti mengajar pelajaran bahasa Indonesia di kelas IV.

\section{d. Refleksi}

Refleksi adalah mengingat dan merenungkan kembali sesuatu tindakan persis dengan yang telah dicatat dalam observasi pada pengalaman mengajar di kelas IV. Pada tahap ini setelah peneliti mengumpulkan serta menganalisis data yang didapatkan dalam tahap pelaksanaan observasi, dan juga hasil evaluasinya. Ini merupakan kegiatan untuk mengemukakan kembali apa yang sudah dilakukan dalam pengalaman mengajar. Pada tahap ini data yang diperoleh dari pengalaman mengajar dianalisis, dan akan digunakan sebagai refleksi. Dari pengalaman mengajar dapat diketahui hasil adanya tindakan, yang dapat digunakan dalam menentukan perencanaan dan tindakan selanjutnya sebagai perbaikan pada siklus pembelajaran berikutnya. Hal ini bertujuan untuk melakukan penyempurnaan pada siklus berikutnya, ketika belum dapat mencapai tujuan yang diharapkan.

\section{Pembahasan}

\section{Permainan Edukatif}

Penelitian ini menggunakan Metode Permainan Edukatif dengan Kartu Kata. Permainan Edukatif adalah semua bentuk permainan yang memiliki sifat untuk mendidik. Menurut Andang (2006:120-121) permainan edukatif (Education 
games), yaitu suatu kegiatan yang sangat menyenangkan dan dapat merupakan cara atau alat pendidikan yang bersifat mendidik. Permainan edukatif juga dapat berarti sebuah bentuk kegiatan yang dilakukan untuk memperoleh kesenangan atau kepuasan dari cara atau alat pendidikan yang digunakan dalam kegiatan bermain.

Hal tersebut juga dikatakan oleh Plato, Aristoteles, Frobel, (Maykes, 2001:2) yang menganggap bermain sebagai kegiatan yang mempunyai nilai praktis. Artinya, bermain digunakan sebagai media untuk meningkatkan ketrampilan dan kemampuan tertentu pada anak.

Alat permainan edukatif bukan berarti harus mahal, buatan dari pabrik dan modern. Alat permainan edukatif (APE) juga dapat ditemukan di lingkungan sekitar anak itu sendiri dengan memanfaatkan sumber daya alam yang ada tanpa mengeluarkan biaya bahkan dapat diperoleh secara cuma- cuma. Karena pada dasarnya alat permainan merupakan alat permainan yang berfungsi menghibur, mendidik, dan mengembangkan kemampuan anak.

Menurut Andang, (2006:152- 153) permaianan edukatif sangat penting untuk anak,sebab:

a. Permainan edukatif dapat meningkatkan pemahaman terhadap

b. Permainan edukatif dapat meningkatkan kemampuan berkomunikasi.

c. Permainan edukatif dapat meningkatkan kemampuan hal- hal baru

d. Permainan edukatif dapat meningkatkan kemampuan berfikir anak

e. Permainan edukatif dapat mempertajam perasaan anak

f. Permainan edukatif dapat memperkuat rasa percaya diri anak

g. Permainan edukatif dapat merangsang imajinasi anak.

h. Permainan edukatif dapat melatih kemampuan berbahasa anak

i. Permainan edukatif dapat melatih motorik halus dan motorik kasar

j. Permainan edukatif dapat membentuk moralitas anak

k. Permainan edukatif dapat melatih ketrampilan anak

1. Permainan edukatif dapat mengembangkan sosialisasi anak

m. Permainan edukatif dapat membentuk spiritualitas anak. 
Permainan edukatif dapat membuat anak memahami kemampuanya secara total atau sepenuhnya karena lewat bermain mereka akan berekspresi secara natural dan tanpa adanya unsur terpaksa maka segala kemampuannya akan tertuangkan dalam bermain. Mengingat dalam bermain tidak bisa lepas dari komunikasi, bahkan adanya sesuatu yang baru dalam bermain membuat anak penasaran dan dapat merangsang imajinasi, mendorong anak untuk berfikir dan berani serta percaya diri mengungkapkan apa yang dipikirkannya. Ketika permainan oleh anak, mereka akan terbiasa untuk berlatih bersosialisasi dengan adanya keanekaragaman sifat setiap anak. Sehingga dengan sendirinya akan terlatih dan terbentuk moral yang baik serta tahu bagaimana cara menghargai.

\section{Prestasi Belajar}

Winkel (Sunarto, 2009) mengemukakan bahwa prestasi belajar merupakan bukti keberhasilan yang telah dicapai oleh seseorang. Maka prestasi belajar merupakan hasil maksimum yang dicapai oleh seseorang setelah melaksanakan usaha- usaha belajar.mempelajari materi pelajaran yang dinyatakan dalam bentuk nilai atau raport setiap bidang studi setelah mengalami proses belajar mengajar. Prestasi belajar siswa dapat diketahui setelah diadakan evaluasi.Hasil dari Evaluasi dapat memperlihatkan tentang tinggi atau rendahnya prestasi belajar siswa.

\section{Pembelajaran Bahasa Indonesia}

"Pembelajaran adalah proses interaksi peserta didik dengan sumber belajar pada suatu lingkungan belajar" (Alben, 2006:63). Sedangkan pembelajaran menurut Hamelik Trianto (2009:17) "Pembelajaran merupakan aspek kegiatan manusia yang kompleks, yang tidak sepenuhnya dapat dijelaskan”. Pembelajaran secara simpel dapat diartikan sebagai produk interaksi berkelanjutan antara pengembangan dan pengalaman hidup. Pembelajaran dalam makna kompleks adalah usaha sadar dari seorang guru untuk membelajarkan siswanya (mengarhkan interaksi siswa dengan sumber belajar lainnya) dalam rangkan mencapai tujuan yang diharapkan. Adapun karakter siswa kelas IV SD sebagaimana yang disampaikan Nasition (Noname:2008) bahwa, siswa kelas IV SD mempunyai beberapa sifat khas sebagai berikut : 
a. Adanya minat terhadap kehidupan praktis sehari- hari yang kongkrit.

b. Amat realistic, ingin tahu dan ingin belajar.

c. Menjelang akhir masa ini telah ada minat terhadap hal- hal dan mata pelajaran khusus, oleh ahli yang mengikuti teori factor ditaksirkan sebagai mulai menonjolnya factor-faktor.

d. Pada umumnya anak menghadapi tugas- tugasnya dengan bebas dan berusaha menyelesaikan sendiri.

e. Pada masa ini anak memandang nilai (angka rapor) sebagai ukuran yang tepat mengenai prestasi sekolah.

f. Anak pada masa ini gemar membentuk kelompok sebaya, biasanya untuk bermain bersama- sama.

\section{Pantun}

Pantun merupakan salah satu karya sastra Melayu yang sampai sekarang masih dikembangkan. Kata pantun memputeorinyai arti ucapan yang teratur, pengarahan yang mendidik. Pantun juga dapat berarti sindiran. Zaman dahulu, pantun digunakan sebagai bahasa pengantar atau bahasa pergaulan. Pantun dikenal di beberapa daerah, namun dengan nama yang berbeda. Di Jawa Tengah dikenal dengan parikan, di Toraja dikenal dengan nama bolingoni, di Jawa Barat dapat ditemukan pantun dalam bentuk nyanyian doger, Di Surabaya Ludruk, di Banjarmasin tirik dan ahui, gandrung di Banyuwangi, dan di Makasar kelongkelong. Selain merupakan ungkapan perasaan, pantun dipakai untuk menghibur orang (Noname,2008).

Senada dengan yang sudah disampaikan di atas, Kaswan dan Rita (2008 : 77) juga menyebutkan bahwa pantun adalah jenis puisi melayu lama yang satu baitnya terdiri atas empat larik dan bersajak a-b-a-b. Larik pertama dan kedua berupa sampiran, sedangkan larik ketiga dan keempatr berupa isi.Sampiran tidak berisi maksud, hanya diambil rima persajaknya.Jadi jika hendak membuat pantun, sebaiknya membuat dulu isinya, kemudian menyusul sampirannya. Menurut Edi dan Farika (2008:89), pantun merupakan bentuk puisi lama yang dikenal luas dalam berbagai bahasa di nusantara. Dalam bahasa Jawa pantun dikenal sebagai parikan. Sedangkan dalam bahasa Sunda, pantun dikenal sebagai paparikan. 
Dari beberapa penjelasan yang disampaikan dari beberapa orang di atas maka dapat disimpulkan sebagaimana yang disebutkan dalam crayonpedia bahwa pantun memiliki cirri- cirri umum sebagai berikut :
a. Mempunyai bait dan isi,
b. Setiap bait terdiri atas baris- baris,
c. Jumlah suku kata dalam tiap baris antara delapan sampaikan dua belas,
d. Setiap bait terdiri atas dua bagian, yang sampiran dan isi,
e. Bersajak $a b a b$

Mengingat sebenarnya pantun sangat lekat dengan masyarakat, maka jika dalam pembelajaran mengenai pantun siswa tidak diajak untuk langsung membuat dan mempraktekannya maka hal demikian hanya menjadi sebuah materi angin lalu saja. Apalagi jika siswa hanya diajak untuk menirukan pantun yang disampaikan guru.

Jenis pantun tema misalnya, pantun anak- anak, jenaka, suka cita, kiasan, nasehat, duka cita, budi pekerti, agama, dll. Sedangkan menurut Umri dan Indriyani (2008: 125) jenis pantun menurut jumlah barisnya ada tiga yaitu :

a. Pantun kilat atau karmina, tiap bait terdiri atas 2 baris Menurut Kaswan dan Rita (2008:107), pantun kilat adalah pantun yang hanya terdiri atas dua larik dan bersajak atau berima a- a. Larik pertama berupa sampiran dan larik kedua berupa isi.

b. Pantun empat seuntai, pantun yang terdiri atas empat baris

c. Talibun, pantun yang terdiri atas $6,8,10,12$ baris dan umumnya bersajak silang ,abc- abc, ab-cd- ab-cd dan seterusnya.

\section{Contoh pantun nasehat :}

Bunga anggrek bunga langit

Warnanya indah menarik hati

Tuntutlah ilmu setinggi langit

Untuk bekal dikemudian hari 


\section{Contoh pantun jenaka :}

Buah pisang buah tomat

Disimpan didalam lumbung padi

Pantas tercium bau menyengat

Rupanya kau belum mandi

Contoh pantun Agama:

Kalau Mufakat Sudah Putus

Peganglah Erat Didalam Hati

Kalau Itikat Sudah Tulus

Disitulah Tempat Hidup dan Mati

\section{Pembelajaran Membuat Pantun Dengan Metode Permainan Edukatif}

Dalam pembelajaran membuat pantun dengan metode permainan untuk kelas 4 dilakukan dengan dua siklus. Sebelum dilakukan siklus 1, terlebih dahuludilakukan pre-test prasiklus satu kali. Kemudian dilanjutkan dengan siklus 1 selama dua kali pertemuan pembelajaran selama 4 x 35 menit. Pada pertemuan pertama, Sub materi yang dibahas adalah ciri - ciri pantun dan jenis- jenis pantun dengan appersepsi berupa tanya jawab tentang perbedaan pantun dengan puisi. Kemudian, siswa berdiskusi mengidentifikasi syarat- syarat pantun. Dilanjutkan dengan permainan kartu kata. Untuk mengetahui pemahaman anak dalam membuat pantun guru memberikan evaluasi berupa test tulis.Dilanjutkan guru membagi siswa menjadi beberapa kelompok.

Kemudian pada pertemuan ke dua, dilaksanakan kegiatan inti kurang lebih 50 menit, dimulai guru menjelaskan pengertian suku kata, sajak, baris, dan bait. Siswa mendiskusikan materi yang ada di LKS yang disediakan guru.Berdasarkan hasil kerja siswa guru membimbing untuk mengidentifikasi syarat- syarat pantun. Setelah itu guru mengajak siswa untuk melakukan permainan dengan kartu kata dengan peraturan yaitu, pertama: kelompok yang lebih dulu selesai mengerjakan dan benar adalah sebagai pemenang. Kedua : susunlah kartu kata menjadi pantun dengan permainan berbalas pantun. Ketiga : majulah ke depan untuk presentasi berbalas pantun.Hasil kerja yang telah ditempel di presentasikan, dikoreksi, 
dibetulkan bersama siswa. Bagi kelompok yang mengerjakan benar dan cepat mendapat reword berupa tepuk tangan dari teman-temannya.

Setelah kegiatan pembelajaran pada siklus I selesai kemudian dilakukan pelaksanaan refleksi. Kegiatan ini dilakukan di ruang kelas IV SD.Muhammadiyah Bausasran Yogyakarta.Berdasarkan hasil refleksi dengan teman sejawat pada pembelajaran siklus I dinyatakan belum berhasil, karena dari 24 siswa, nilai rata- rata yang diperoleh dalam siklus I adalah 66,75. Target KKM nilai rata- rata 75 , karena belum mencapai target maka perlu diadakan perbaikan pembelajaran pada siklus ke II.

Pelaksanaan pembelajaran pada siklus ke II memerlukan waktu 70 menit sesuai dengan alokasi waktu I kali pertemuan 2 x 35 menit. Kegiatan pendahuluan dilaksanakan kurang lebih 10 menit, kegiatan inti 50 menit, kegiatan penutup adalah 10 menit. Kegiatan Pendahuluan ini diawali dengan melakukan presensi, dilanjutkan apersepsi dengan menyampaikan sebuah pantun nasehat, tidak lupa juga guru menampaikan sebuah puisi siswa mendengarkan.Guru memberi pertanyaan- pertanyaan sesuai dengan materi. Berdasarkan anak- anak, guru menyampaikan tujuan pembelajaran dan kegiatan pembelajaran yaitu siswa yang dapat menjawab dan dapat membuat pantun anak menggunakan kartu kata yang disusun oleh guru. Guru membagi siswa menjadi beberapa kelompok, kemudian membagi LKS untuk dikerjakan.

Kegiatan Inti diawali dengan siswa berdiskusi dengan kelompoknya, bahan materi pantun yang sudah disusun dalam LKS. Guru berkeliling sambil menawarkan bimbingan bagi yang memerlukan. Siswa mengerjakan LKS yang berisi tentang teori pantun, LKS yang ke dua siswa bermain dengan kartu kata untuk membuat pantun. Bagi kelompok yang selesai duluan dan pantun tersusun dengan tepat, segera satu kelompok maju ke papan tulis untuk memajangkan hasilnya. Apabila pekerjaan kelompok sadah benar, siswa yang lain memberi semangat dengan tepuk tangan. Pemenangnya adalah kelompok yang selesai menyusun kartu dan susunanya tepat, segera memajangkan hasil di papan tulis. Hasil kerja siswa yang ditempel dibahas bersamna- sama siswa dengan guru. 
Setiap kelompok yang membuat pantun dengan benar maka akan mendapat hadiah dari teman- temannya yaitu tepuk tangan.

Setelah selesai permainan semua siswa kembali duduk ke tempat masingmasing untuk mengerjakan soal secara individu.Kegiatan penutup, pada kegiatan ini siswa bersama dengan guru menyimpulkan materi pelajaran kemudian siswa mencatatnya. Setelah semuanya selesai guru mengajak siswa untuk mereview dan menyimpulkan pembelajaran yang telah disampaikan. Guru menutup pembelajaran dengan menyampaikan pantun nasehat sebagai nasehat untuk siswa.

Pada perbaikan pembelajaran siklus II memfokuskan pada penggunaan bahasa yang mudah dipahami siswa atau bahasa yang komunikatif dalam menginformasikan tujuan dan pada kegiatan menjelaskan tata cara melakukan permainan dengan kartu kata.Kegiatan Inti diawali dengan siswa berdiskusi dengan kelompoknya, bahan materi pantun yang sudah disusun dalam LKS. Guru berkeliling sambil menawarkan bimbingan bagi yang memerlukan. Siswa mengerjakan LKS yang berisi tentang teori pantun, LKS yang ke dua siswa bermain dengan kartu kata untuk membuat pantun. Bagi kelompok yang selesai duluan dan pantun tersusun dengan tepat, segera satu kelompok maju ke papan tulis untuk memajangkan hasilnya.

Apabila pekerjaan kelompok sudah benar, siswa yang lain memberi semangat dengan tepuk tangan. Pemenangnya adalah kelompok yang selesai menyusun kartu dengan cepat dan susunanya tepat, segera memajangkan hasil di papan tulis.Hasil kerja siswa yang ditempel dibahas bersama- sama siswa dengan guru. Setiap kelompok yang membuat pantun dengan benar maka akan mendapat hadiah dari teman- temannya yaitu tepuk tangan.Setelah selesai permainan semua siswa kembali duduk ke tempat masing- masing untuk mengerjakan soal secara individu.

Pada siklus II semua hasil belajar siswa berada di atas KKM (Kriteria Ketuntasan Minimal), penerapan permainan edukatif dalam pembelajaran $79 \%$ dengan rata - rata hasil belajar 78.91. Dengan kondisi hasil refleksi tersebut mengenai penerapan permainan edukatif dalam pembelajaran bahasa Indonesia pada materi pantun siswa kelas IV SD Muhammadiyah Bausaran Yogyakarta 
ternyata dapat menjadikan proses pembelajaran lebih baik, kreatif, dan menyenangkan.

\section{Simpulan}

Berdasarkan hasil penelitian dan pembahasan yang telah dilakukan, dapat disimpulkan bahwa Peningkatan Prestasi Belajar Bahasa Indonesia dengan Metode Permainan Edukatif dalam materi pantun kelas IV di SD Muhammadiyah Bausasran ternyata mengalami peningkatan.

Pelaksanaan pembelajaran di sini dengan menerapkan permainan edukatif yang disesuaikan dengan materi. Adapun permainan yang digunakan dalam penelitian ini yaitu pantun dengan metode permainan edukatif dengan kartu kata dan berbalas pantun.

Dalam pembelajaran dengan permainan tersebur dapat meningkatan hasil pembelajaran pantun di kelas IV. Hasil peningkatan tersebut dapat dilihat dari peningkatan keaktifan dan kreatifitas, kemauan siswa dalam mengikuti pembelajaran dengan permainan edukatif tersebut. Kegiatan belajar siswa walaupun dikerjakan dalam kelas siswa tetap antusias, lebih komunikatif, kreatif, dan menyenangkan.

Dalam penyampaian materi guru mengacu pada standar kompetensi dan kompetensi dasar kurikulum yang kemudian dijabarkan atau dituangkan dalam RPP. Instrumen yang digunakan sebagai perangkat pembelajaran dalam penelitian ini adalah lembar observasi.

Berdasarkan data yang diperoleh, pelaksanaan proses pembelajaran mengalami peningkatan antara nilai prasiklus dengan siklus I adalah naik 3,58, sedangkan dari siklus I ke siklus II meningkat sebesar 8,58. Sebelum diadakan penelitian siswa yang tidak mencapai KKM ada 18 anak dari jumlah 24, hanya 6 anak yang mencapai KKM. Pada siklus I siswa yang mencapai KKM ada 9 siswa. Pada siklus II yang mencapai KKM ada 21 siswa. Sehingga penelitian ini dihentikan sampai siklus II saja. Karena dalam siklus II sudah terjadi peningkatan dan hasil yang diharapkan.

Dalam sisi lain permainan edukatif dapat memberikan rasa senang, semangat, keaktifan, kerja sama, dan ketertarikan pada siswa dalam pembelajaran 
bahasa Indonesia. Selain itu bahasa Indonesia salah satu mata Ujian Negara yang harus dipelajari. Hal demikian karena sesuai dengan karakter siswa Sekolah Dasar. Pelaksanaan pembelajaran yang berlangsung sesuai dengan dunia anak yaitu bermain karena menggunakan permainan edukatif. Permainan edukatif selama pembelajaran tidak membuat siswa pasif, tetapi di sana membutuhkan peran aktif siswa. Siswa yang senang bergerak tersalurkan keinginannya tersebut. Dalam pembelajaran siswa bergerak untuk mencari pasangan kartu kata, kemudian mereka berlari ke papan tulis untuk menyusunnya menjadi sebuah kalimat pantun.

Mengingat siswa juga senang bekerja dalam kelompok, Hal demikian juga dapat dilaksanakan dalam permainan kelompok. Penerapan permainan ini bisa juga memeragakan sesuatu secara langsung. Hal demikian terjadi ketika siswa langsung membuat pantun sendiri bahkan membacakan pantunnya dengan peragaan berbalas pantun. Sehingga siswa tidak hanya hafal dengan contoh yang diberikan guru, tetapi mereka bisa membuat pantun baik dengan kartu kata ataupun dengan berbalas pantun.

\section{Daftar Pustaka}

Alben, Ambarita. (2006). Manajemen Pembelajaran. Jakarta : Departemen Nasioanal Jenderal Pendidikan Tinggi Direktorat Ketenagaan

Andang, Ismail. (2006).Education Games. Yogyakarta : Pilar Media

Dadan, Djuanda. (2006). Pembelajaran Bahasa Indonesia yang Komunikatif Menyenangkan.Jakarta : Depdiknasdikti.

Darmadi, Kaswan\&Nirbaya, Rita. (2008). Bahasa Indonesia 4. Jakarta: Pusat Perbukuan Departemen Pendidikan Nasional

Indriyani,Umri Nur'aini. (2008).Bahasa Indonesia untuk Kelas IV. Jakarta: Pusat Perbukuan, Departemen Pendidikan Nasional

Maykes, Tedjosaputra S. (2001). Bermain Mainan dan Permainan. Jakarta : Grasindo. 
Noname, (2008) Penulisan Pantun. Artikel. Diambil dari http://www.crayonpedia.org/mw/Penulisan Pantun 7.1 diakses pada tanggal 16 Juli 2014

Suharsimi, Arikunto,dkk.(2006). Penelitian Tindakan Kelas. Jakarta : Bumi Aksara

Sunarto. (2009) Pengertian Prestasi Belajar. Artikel diambil dari http.//sunartombs.wordpress.com/2009/01/05/ Pengertian-Prestasi _ Belajar/. Diakses pada tanggal 18 Juli 2014

Trianto. (2009). Mendesain Model Pembelajaran Inovatif-Progresif. Jakarta: Kencana

Warsidi, Edi\&Farika. (2008). Bahasa Indonesia Membuatku Cerdas untuk Kelas $5 S D$ —Jakarta: Pusat Perbukuan, Departemen Pendidikan Nasional 